\section{Planting Date and Romaine Lettuce Cultivar Affect Quality and Productivity}

\author{
Robert J. Dufault, Brian Ward, and Richard L. Hassell \\ Coastal Research and Education Center, Department of Horticulture, Clemson \\ University, 2700 Savannah Highway, Charleston, SC 29414
}

Additional index words. Lactuca sativa L. var. longifolia Lam., cold tolerance, phenology, stress, asteraceae

Abstract. The objective of this study was to determine the best combination of planting dates (PDs) and cultivars on yield and quality for long-term production of romaine lettuce. 'Green Forest' (GF), 'Apache' (AP), 'Darkland' (DK), 'Green Tower' (GT), 'Ideal Cos' (IC), and 'Tall Guzmaine' (TG) were successfully grown to harvest maturity on 19 PDs from September 1998 to April 2001. Lettuce planted in September and April PDs (pooled over cultivars and year), required as little as 47 and 49 days, respectively, to reach harvest (all cultivars harvested on the same day). Lettuce planted in October, November, February, and March PDs (pooled over cultivars and year), required on average 64, 66, 75, and 67 days to reach harvest, respectively, but in the coldest PDs of December and January, 90 and 98 days, respectively, were needed to reach maturity. Of the eight PDs evaluated, marketable numbers/plot (pooled over cultivars and years) were greatest in the September PD, followed by April (-8\% decrease from September PD) $>$ March $(-13 \%)>$ October $(-17 \%)>$ November $(-21 \%)>$ December $=$ January $=$ February $($ about $-30 \%)$ and heads weighed the most in September $>$ January $=$ February $(-7 \%$ decrease from September PD) $>$ March $=$ April $(-14 \%)>\operatorname{October}(-21 \%)>\operatorname{December}(-25 \%)>\operatorname{November}(-31 \%)$. Cull heads/plot (pooled over cultivars and years) were greatest in April $>$ December $(-5 \%$ decrease from April PD) $>$ January $=$ February $(-16 \%)>$ November $(-27 \%)>$ October $(-34 \%)>$ March $(-44 \%)>$ September $(-49 \%)$. Two out of three November PDs were lost to freezing damage and this PD should be avoided. Significant bolting occurred primarily in the September and October PDs (in 1 of 3 years) with negligible bolting in the November, December, and January PDs, but bolting recurred again in the February, March and April PDs. Marketable numbers/plot (pooled over all PDs and years) were greatest for GF $>$ GT $(-7 \%$ decrease from GF $)>$ AP $(-8 \%)>$ IC $(-9 \%)>$ DK $(-11 \%)>$ TG $(-21 \%)$. The interaction effect of cultivar $\times$ PD indicated that GF yielded the most marketable heads in 6 out of 8 PDs. The best performing cultivars by PD (pooled over years) were September and February $=$ GF and IC; October $=$ TG; November $=$ AP; December, January, March,

and April = GF .

Over the past 15 years, romaine lettuce (also known as Cos) has become one of the U.S.'s most popular vegetables in terms of production, consumption, and exports [(US. Dept. of Agriculture(USDA), 2005]. Romaine per capita consumption in the U.S. has tripled since 1994, when it averaged $1.0 \mathrm{~kg}$, but by 2004, per capita use has reached a record 3.7 $\mathrm{kg}$, up $>1.8 \mathrm{~kg}$ from 1999. Although California, New Jersey, and Arizona are the dominant suppliers of romaine lettuce, areas such as South Carolina, could supply Southeast markets for fall, winter and spring production. To capture significant portions of the market, long-term production from fall to spring would be desirable. Romaine lettuce grows well in the Charleston, S.C., area and 'Parris Island Cos' was developed by Clemson University-USDA in 1955 to met local demand.

To meet the changing market demands during the season, growers need to make frequent plantings and select cultivars that perform well and are best-suited to unique growing condi-

Received for publication 14 Nov. 2005. Accepted for publication 12 Jan. 2006.

yplanting date not completed in that month. any internal or exposed seed stems and have healthy defect-free visual appearance. Various research studies have been published in diverse locations on different lettuce types evaluating planting dates (PDs) for lettuce production such as India (Sharma et al., 2001), Poland (Kobryn, 2001), United Kingdom (Wurr et al., 1988); Saudi Arabia (Al-Harbi, 2001), Australia (de Vaus, 1976), and Denmark (Kristensen et al., 1987). The conclusions reached in these studies are specific to those regions because of the genotype $\times$ environment interactions that modifies plant growth specific to unique climatic conditions. Differences in temperature and/or light levels (i.e., daylength, solar radiation intensity and quality), soil types, and a milieu of other microclimatic conditions make extrapolation of others' results to our region difficult, if not impossible. In order for PD and cultivar selection for commercial production to be successful in any locality, research needs to be done near potential commercial production sites. The objective of this study was to determine the best combination of PDs from September to April and various cultivars, on the yield and quality for long term production of romaine lettuce.

\section{Materials and Methods}

In total, 22 PDs were chosen for this study from 1998 to 2001 (Table 1). Late summer, fall, winter and spring PDs were selected to establish the feasibility of long term romaine production and also to identify the latest successful PD possible in the Charleston, S.C., area. There were 8 PDs in the 1998-99 GS, 6 in the 1999-00 GS, and 8 in the 2000-01 GS with each PD separated about 1 month from early September to early April. Seeds of six romaine lettuce cultivars - 'Green Forest' (GF), 'Apache' (AP), 'Darkland' (DK), 'Green Tower'(GT), 'Ideal Cos'(IC), and 'Tall Guzmaine' (TG) - were planted in a plug flat (TLC 288 Polyform; Plymouth, Maine) (top, $2.1 \times 2.1 \mathrm{~cm}$; bottom, $1.3 \times 1.3 \mathrm{~cm}$; depth, 3.2 $\mathrm{cm}$; cell volume, $9.5 \mathrm{~cm} 3$ ) filled with a peat and vermiculite medium (Redi-Earth Terralite mix, W.R. Grace \& Co., Allentown, Pa.). The seedlings for all PDs were grown for 4 weeks in the greenhouse. Drip-irrigated, methyl bromide (Sanders, 2005) fumigated raised beds $(15 \mathrm{~cm}$ in height) on 1.8 -m centers were fertilized with $120 \mathrm{~N}-53 \mathrm{P}-104 \mathrm{~K} \mathrm{~kg} \cdot \mathrm{ha}^{-1}$, covered with black plastic mulch. Seedlings were transplanted in $6.1 \mathrm{~m}$ long, triple rows spaced $23 \mathrm{~cm}$ apart,

Table 1. Planting and harvest dates of romaine lettuce cultivars ${ }^{\mathrm{z}}$ from 1998 to 2001.

\begin{tabular}{|c|c|c|c|c|c|}
\hline \multicolumn{2}{|c|}{ 1998-99 } & \multicolumn{2}{|c|}{ 1999-00 } & \multicolumn{2}{|c|}{ 2000-01 } \\
\hline $\begin{array}{l}\text { Planting } \\
\text { date }\end{array}$ & $\begin{array}{c}\text { Harvest } \\
\text { date }\end{array}$ & $\begin{array}{c}\text { Planting } \\
\text { date }\end{array}$ & $\begin{array}{c}\text { Harvest } \\
\text { date }\end{array}$ & $\begin{array}{c}\text { Planting } \\
\text { date }\end{array}$ & $\begin{array}{c}\text { Harvest } \\
\text { date }\end{array}$ \\
\hline 1 Sept. & Crop failure & $---^{y}$ & --- & 15 Sept. & 1 Nov. \\
\hline 1 Oct. & 5 Dec. & 5 Oct. & 14 Dec. & 2 Oct. & 29 Nov. \\
\hline 2 Nov. & 7 Jan. & 1 Nov. & 1Froze & 1 Nov. & Froze \\
\hline 1 Dec. & 2 Mar. & 1 Dec. & 3 Mar. & 1 Dec. & 21 Mar. \\
\hline 4 Jan. & 8 Apr. & 4 Jan. & 29 Mar. & 4 Jan. & 5 Apr. \\
\hline 1 Feb. & 3 May & $1 \mathrm{Feb}$. & 7 Apr. & 6 Feb. & 16 Apr. \\
\hline 1 Mar. & 11 May & 1 Mar. & 11 May & 1 Mar. & 30 Apr. \\
\hline 1 Apr. & 18 May & $---{ }^{y}$ & --- & 2 Apr. & 22 May \\
\hline
\end{tabular}

z'Apache', 'Darkland', 'Green Forest', 'Green Tower', 'Ideal Cos', and 'Tall Guzmaine'. 
with $23 \mathrm{~cm}$ between plants within rows. The experiment was a randomized complete block design with four replications. The soil was a Yauhannah loamy fine sand (Aquic Hapludults). Commercially accepted pest management and similar cultural practices were used for all PDs (Sanders, 2005). Propyzamide (a.i.) at $4.4 \mathrm{~kg} \cdot \mathrm{ha}^{-1}$ was applied to the soil between mulched beds. Air temperatures were continuously monitored during the 3-year period using a weather station (Campbell Inc., Logan, Utah). The mean growing season temperature was calculated by taking the daily mean max and min temperatures from the $24 \mathrm{HR}$ period from seedling transplanting to head harvest for all years the PD was made and averaged to derive this overall mean temperature that could be used as a relative comparison of growing season climate.

All lettuce PDs were harvested once on the same day when the majority of heads were judged to weigh $\geq 0.45 \mathrm{~kg}$. The day before harvest, the height of five randomly chosen heads per row were measured from ground level to top of the head in the field and also field-rotten heads per plot were counted. Individual heads were cut at the soil level, weighed and graded for marketability according to USDA standards (USDA, 1960). The single most dominant head quality defect that would cause nonmarketability was characterized on each cull head including undersized, bolted, or cold temperature damaged. In our study, heads $<0.23 \mathrm{~kg}$ in weight and/or excessively short were classified as undersized and cull. Bolted heads included: flowered heads; heads with a puckering of the center; and heads with undeveloped floral parts apparent with some manual probing. Cold temperature damaged heads exhibited leaf-tissue burning caused by collapse of tissue from previous freezing. Each cull defect including field rots was calculated as the percent incidence of all total cull defects and these percentages were arcsine-transformed using Sigma Stat software (Systat Software, Inc., Point Richmond, Calif.). PROC GLM procedure of PC SAS (SAS Institute, Cary, N.C.) was used to analyze the effects of PD, cultivar, and year (year) by ANOVA. If the F test was significant at $P=0.05$, the means were separated by LSD at $P=0.05$. LSD's were performed on transformed cull percentage data and mean separation applied to nontransformed means. The relative importance of PD, cultivar and year factors were determined by partitioning the total sum of squares for ANOVA sources into main and interaction effects and expressing these individual contributions to variation as a percentage of the sum of squares for the model (composed of only those sources of variation in the ANOVA). The value of these percentages is that they become very useful indicators of which factors were more potent in affecting growth, quality and yield variables relative to the other factors.

\section{Results and Discussion}

Harvestmaturity. Romaine lettuce cultivars were successfully grown to harvest maturity on nineteen PDs from September 1998 to
April 2001 (Table 1). The PDs were spaced one month apart but in some years, not all PDs were successful and/or planted. In the first year (1998-99), the first PD in September was lost due to herbicide injury and the September PD was not attempted in the second year. In the second and third years, all lettuce heads in the November PDs were frozen and destroyed before harvest and planting in November is too risky for commercial use since $66 \%$ of all plantings were lost due to freezes. Each PD experienced unique climatic conditions (rainfall, daylength, day/night temperature fluctuations, etc.) and temperatures in some fall PDs were similar to some late winter and spring PDs (Fig. 1). For example, mean growing season temperatures were similar (within two degrees or less) for the following PD pairs: September and April; October and March; and November and February; however, fall PDs became progressively colder with shorter days throughout their GS. Winter and early spring PDs, conversely, progressively warmed with longer days, which affected yield and quality differentially. Of all the PDs, the December PD growing season experienced the coldest temperatures followed by January PDs.

Lettuce planted in September, on average, required as little as $47 \mathrm{~d}$ to reach harvest maturity, which was similar to lettuce planted in April, requiring $49 \mathrm{~d}$ to mature (Fig. 1). As the weather became progressively colder through the fall and winter months, days to harvest maturity naturally increased. The GS for the lettuce planted in October, November, February and March PDs were similar requiring on average $64,66,75$, and $67 \mathrm{~d}$, respectively, to reach harvest maturity. Lettuce planted during the coldest months in December and January, required 90 and 98 days, respectively, the longest time for lettuce to reach head maturity.

Yield and quality differences. The goal for growing romaine lettuce for commercial sale should be to produce over a long time period, defect-free, long and heavy heads. Each PD experienced unique climatic conditions (rainfall, daylength, day/night temperature fluctuations, etc.), which varied by year (Table 2). Examination of the main effects of PDs is useful to show the general trends for optimal performance of lettuce but it was expected that individual cultivars may vary by PD and year.

Lettuce yield was affected by PD with the $19 \%$ of the variation in marketable number/plot assigned to the main effects of PD and cultivar and their interactions (Table 3). Yields were also affected by year which interacted with PD and cultivar. Yield in all PDs was greatest in 2000, lowest in 1999 and intermediate in 1998 (data not shown). The numbers of marketable heads/plot were greatest in the Sep PD GS followed by April (-8\% decrease from September $)>\operatorname{March}(-13 \%)>$ October $(-17 \%)>$ November $(-21 \%)>$ December $=$ January $=$ February (about $-30 \%$ ) (Fig. 2a). The November PD GS was the most risky time to grow romaine since freezes in the second and third years, severely singed the leaf tips and destroyed quality as the crop neared harvest. Generally, marketable numbers per plot were $5 \%$ lower in the only successful November
PD (1998-99) than the October PD. Marketable head yields were lowest of all PDs with the December, January and February PDs. In general, temperatures during the December PD GS in the second and third years were not similar to any other PD and the coldest of all PD GSs. Despite these low temperatures, head maturation in the December PD occurred after the threat of freezing damage had past and head loss due to freezing was not a problem then. All three year repetitions of the December, January, and February PDs developed to harvest and these PDs are commercially feasible although these PDs were the lowest yielding of all. The most productive cultivars by PD were September and February $=$ GF and IC; October $=\mathrm{TG}$; November $=\mathrm{AP}$; and December, January, March and April = GF.

Seventeen percent of the total variation in both head weight and length were attributable to PD and cultivar main effects and their interaction (Table 3). Significant variation in head weight and length was also assigned to year and its interaction with PD and cultivar indicating that climatic conditions unique each year, moderated these head quality factors. Generally, head weight was greatest in the third year in all PDs (except the March and April PDs with greatest head weight in the first year) and lowest in the second year (data not shown). Head weight varied significantly with PDs with the following hierarchy from heaviest to lightest heads (pooled over cultivar and year): September $>$ January $=$ February $(-7 \%$ decrease from September $)>$ March $=$ April $(-14 \%)>$ October $(-21 \%)>$ December $(-25 \%)>$ November $(-31 \%)$ (Fig. 2b). The heads of GF and TG were the heaviest of all cultivars in general (pooled over PDs and year), but cultivar superiority varied by PD. The heaviest heads by cultivar and PD (pooled over year) were: Sep and November $=$ all cultivars similar; October $=$ all cultivars similar except GT was lighter; December $=$ all cultivars similar, except DK and GT were lighter; January $=$ GF and TG; February = GF, GT, and TG; and March and April = GF. Head length also varied by PDs with longest heads in the September PD $>$ October $=$ April $(-11 \%$ decrease from September $)>$ November $(-13 \%)>$ December through March $(-16 \%)$ which were similar and shortest (Fig. 2c). IC produced the longest heads in general (pooled over PDs), but length varied within each PD by cultivar. GF produced the longest heads in November, January, March, and April and IC produced the longest heads in all PDs except November.

Cull defects and yield. Cull head defects included the incidence of bolting, undersized, cold temperature damaged and field rots. Bolting caused significant reductions in marketability in some early fall PDs as well as some late winter, early spring PDs, apparently since climatic conditions favored flower stalk initiation (Fig. 3a). In total, $19 \%$ of the variation in head bolting was assigned to the main effects and interaction of PD and cultivar, but the yearly climatic differences within PD, introduced significant portions of variation (Table 3). More than $16 \%$ of the culls in 1998 bolted, 


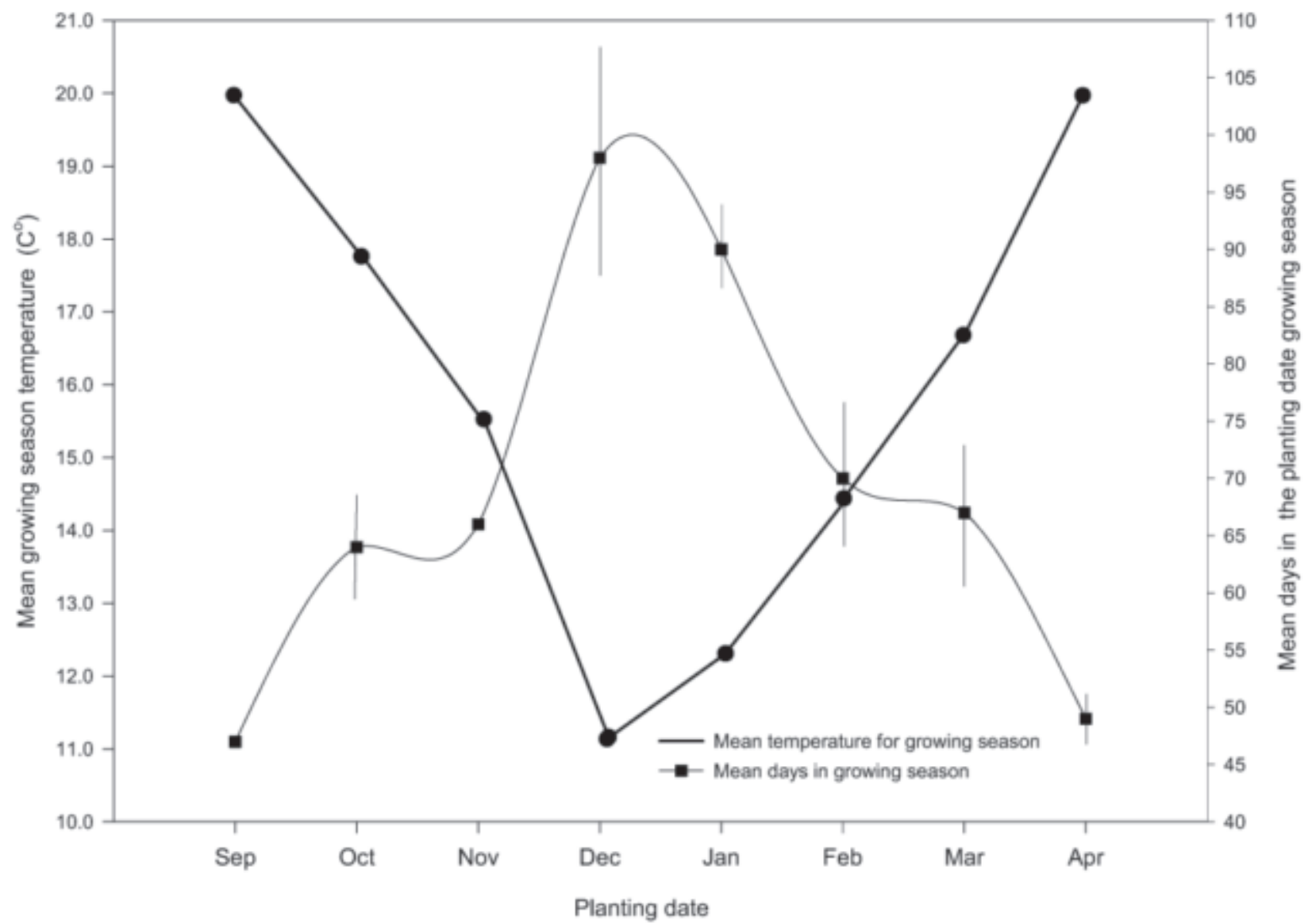

Fig. 1. Mean monthly growing season temperatures and length of growing seasons of romaine lettuce planted monthly from September to April 1998 to 2001. The mean growing season temperature was calculated by taking the daily mean max and min temperatures in a 24-h period from seedling transplanting to head harvest for the three years and averaging these to derive an overall mean temperature that could be used as a relative comparison of growing season climate. Bars through temperature points are the standard deviation due to yearly temperature differences.

yet only 3\% in both 1999 and 2000, so apparently the environmental conditions for bolting

(in this case, temperature since daylength did not change) were not achieved in 1999 and

Table 2. Climatic conditions during the growing seasons of romaine lettuce transplanted on eight different planting dates from September to April 1998 to 2001.

\begin{tabular}{|c|c|c|c|c|c|}
\hline \multirow{2}{*}{$\begin{array}{l}\text { Planting } \\
\text { date }\end{array}$} & \multirow[b]{2}{*}{ Year } & \multicolumn{3}{|c|}{ Temp $\left({ }^{\circ} \mathrm{C}\right)$} & \multirow{2}{*}{$\begin{array}{c}\text { Rainfall } \\
(\mathrm{cm})\end{array}$} \\
\hline & & Mean & Max & Min & \\
\hline September & 2000 & 19.4 & 26.6 & 13.3 & 5.1 \\
\hline \multirow[t]{3}{*}{ October } & 1998 & 18.9 & 25.0 & 12.2 & 5.5 \\
\hline & 1999 & 16.7 & 22.8 & 11.7 & 20.7 \\
\hline & 2000 & 15.0 & 22.8 & 8.9 & 5.6 \\
\hline Mean & & 16.7 & 23.3 & 11.1 & 10.6 \\
\hline November & 1998 & 15.0 & 20.0 & 9.4 & 14.0 \\
\hline \multirow[t]{3}{*}{ December } & 1998 & 12.2 & 18.3 & 6.7 & 25.0 \\
\hline & 1999 & 10.0 & 16.7 & 3.3 & 18.7 \\
\hline & 2000 & 9.4 & 15.5 & 3.9 & 24.9 \\
\hline Mean & & 10.5 & 16.7 & 5.0 & 22.9 \\
\hline \multirow[t]{3}{*}{ January } & 1998 & 12.2 & 19.4 & 6.1 & 17.4 \\
\hline & 1999 & 11.1 & 18.3 & 5.0 & 22.2 \\
\hline & 2000 & 12.2 & 18.3 & 6.7 & 20.9 \\
\hline Mean & & 12.2 & 18.9 & 5.6 & 20.2 \\
\hline \multirow[t]{3}{*}{ February } & 1998 & 14.4 & 21.1 & 8.3 & 27.4 \\
\hline & 1999 & 13.3 & 21.1 & 6.7 & 13.6 \\
\hline & 2000 & 15.0 & 21.1 & 9.4 & 19.3 \\
\hline Mean & & 14.4 & 21.1 & 8.3 & 20.1 \\
\hline \multirow[t]{3}{*}{ March } & 1998 & 16.7 & 23.3 & 10.5 & 14.1 \\
\hline & 1999 & 17.2 & 23.9 & 10.5 & 12.0 \\
\hline & 2000 & 15.5 & 22.2 & 9.4 & 15.3 \\
\hline Mean & & 16.1 & 22.8 & 10.0 & 13.8 \\
\hline \multirow[t]{2}{*}{ April } & 1998 & 19.4 & 26.1 & 14.4 & 16.3 \\
\hline & 2000 & 20.0 & 26.6 & 13.3 & 2.8 \\
\hline Mean & & 19.4 & 26.6 & 13.9 & 9.6 \\
\hline
\end{tabular}

2000 (data not shown). More bolting occurred in the September and October PD GSs with negligible bolting in the November, December and January PD GSs, but increasing again in the February, March and April PD GSs. In the September 2000 PD (only one September PD completed), minimum, maximum, and mean temperatures were $13.3,26.6$, and $19.4{ }^{\circ} \mathrm{C}$, respectively, and $13 \%$ of all culls were bolted (Table 2). In the October $1998 \mathrm{PD}$, the only PD of the three year with significant bolting, min., max, and mean temperatures were 12.2, 25.0 , and $18.9^{\circ} \mathrm{C}$, respectively, and $53 \%$ of all culls were bolted. In the 1999 and 2000 October PD growing seasons, min, max and mean temperatures were much lower in comparison. Ryder (1999) reported flowering was not accelerated at a growing temperature of $10^{\circ} \mathrm{C}$, but increasingly accelerated at $15.5,18$, and $21{ }^{\circ} \mathrm{C}$; lower root temperatures delayed flowering and the combined effect of vernalization, long days and high temperatures produced maximum bolting acceleration.

The production of field rots and undersized heads were, in general, the primary and secondary most common cull defects, respectively. The incidence of field rots was caused by Sclerotia rolfsii infection with subsequent collapse of the heads in the field. This defect was affected by PD, cultivar and their interaction (Table 3 ), but the majority of variation was 
Table 3. Percentages of treatment sum of squares of the model partitioned into main and interaction effects for romaine lettuce yield variables in response to planting dates, cultivars, and year of planting.

\begin{tabular}{|c|c|c|c|c|c|c|c|c|}
\hline \multirow{2}{*}{$\begin{array}{l}\text { Source of } \\
\text { variation }\end{array}$} & \multirow{2}{*}{$\begin{array}{c}\text { Marketable } \\
\text { no./plot }\end{array}$} & \multirow{2}{*}{$\begin{array}{c}\text { Head } \\
\text { wt }\end{array}$} & \multirow{2}{*}{$\begin{array}{l}\text { Head } \\
\text { length }\end{array}$} & \multirow{2}{*}{$\begin{array}{c}\text { Cull } \\
\text { no./plot }\end{array}$} & \multicolumn{4}{|c|}{ Incidence of cull defect } \\
\hline & & & & & Bolt & Undersize & Cold damage & Field rot \\
\hline Planting date (PD) & $8^{* * *}$ & $14^{* * *}$ & $2^{* * * *}$ & $5^{* * *}$ & $11^{* * *}$ & $1^{* * * *}$ & $33^{* * *}$ & $15^{* * *}$ \\
\hline Year $(\mathrm{Y})$ & $7^{* * *}$ & $14^{* * *}$ & $10^{* * *}$ & $4^{* * *}$ & $8^{* * *}$ & $6^{* * * *}$ & $1^{* * *}$ & $24^{* * *}$ \\
\hline $\mathrm{PD} \times \mathrm{Y}$ & $13^{* * * *}$ & $2^{* * * *}$ & $7^{* * * *}$ & $11^{* * *}$ & $15^{* * *}$ & $6^{* * * *}$ & $10^{* * * *}$ & $9^{* * * *}$ \\
\hline $\mathrm{C} \times \mathrm{Y}$ & $2^{* * *}$ & $1^{* * * *}$ & $1^{* * * *}$ & $2^{* * *}$ & $4^{* * *}$ & $3^{* * * *}$ & $0^{\mathrm{NS}}$ & $6^{* * * *}$ \\
\hline
\end{tabular}

$\mathrm{NS}, * *, * * * *^{*}$ test nonsignificant at $P=0.05$ or significant at $P=0.01$ and 0.001 level, respectively.
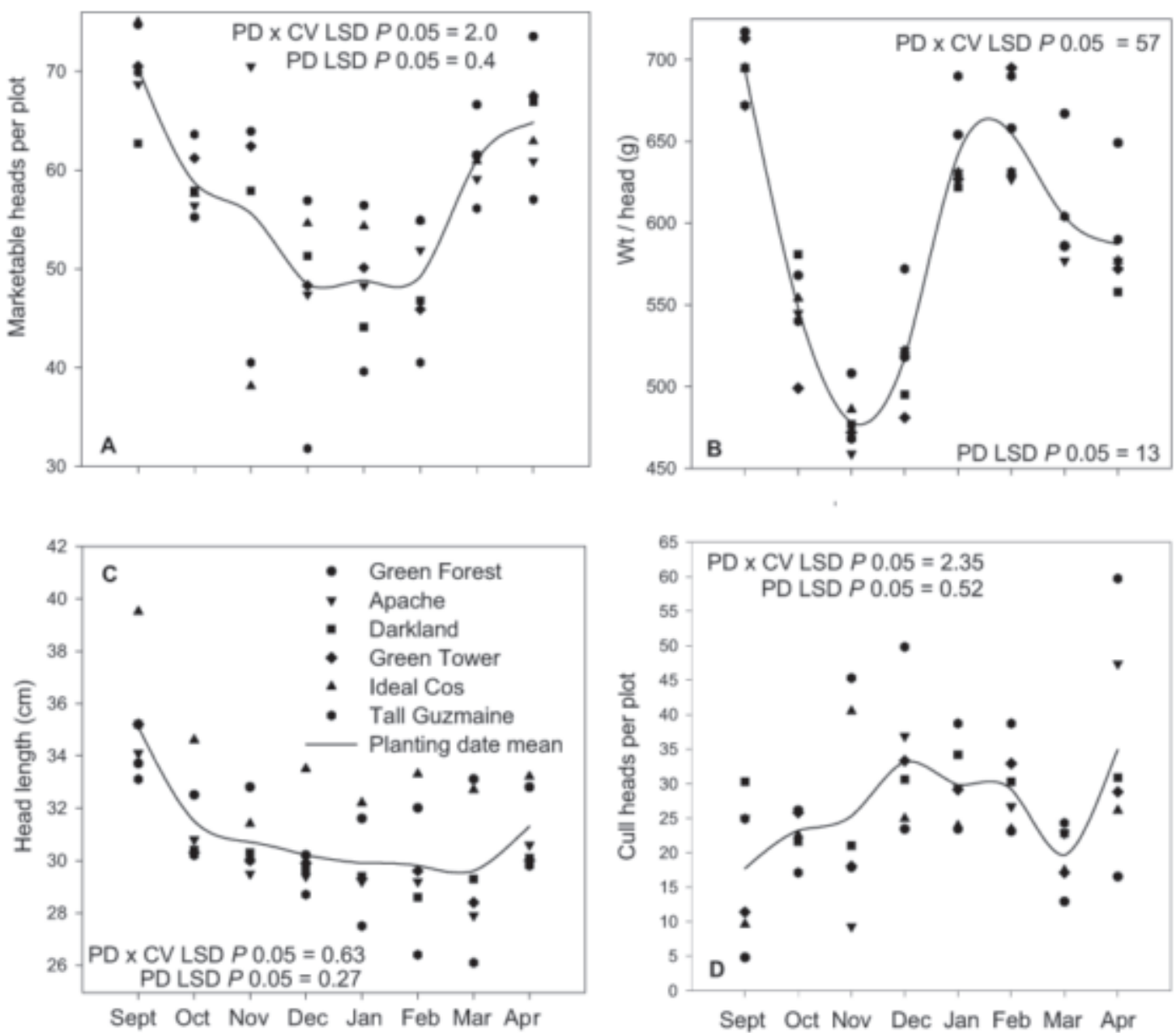

Planting Date

Fig. 2. Influence of monthly planting dates from September to April 1998 to 2001 and seven romaine lettuce cultivars in Charleston, S.C., on (a) marketable heads per plot, (b) individual marketable head weight, (c) marketable head length, and (d) cull heads per plot.

assigned to year, suggesting that there were more favorable climates for disease over the three years the experiment was conducted. In total, $33 \%$ of all culls in 1998 were field rots with $53 \%$ in 1999 and $66 \%$ in 2000 (data not shown). Field rots occurred more in September, December, January, and February PD GSs (Fig. 3d), with all PDs except the September PD experienced the lowest minimum temperatures (Table 2) of all PDs. The incidence of field rots was lower in October, March and April PD GSs (higher minimum temperatures) and the least problematic in November PD GS (this is an artifact of very high losses from freezing damage). Since both November PDs were lost in 1998 and 1999 and field rots were also greater in those years, it is probable that lettuce heads not destroyed by the freeze were subsequently infected through damaged tissue with final collapse as field rots.
With undersized cull heads, smaller portions of variation were assigned to $\mathrm{PD}$ and cultivar effects, but $73 \%$ of the variation was assigned to error (other variables not controlled that affected head elongation) (Table 2). The greatest incidence of undersized heads occurred in 1999 (45\% of all culls), followed by $32 \%$ in 1998 and $18 \%$ in 2000 (data not shown). Undersized heads were greatest in October, January, October, March, and April 

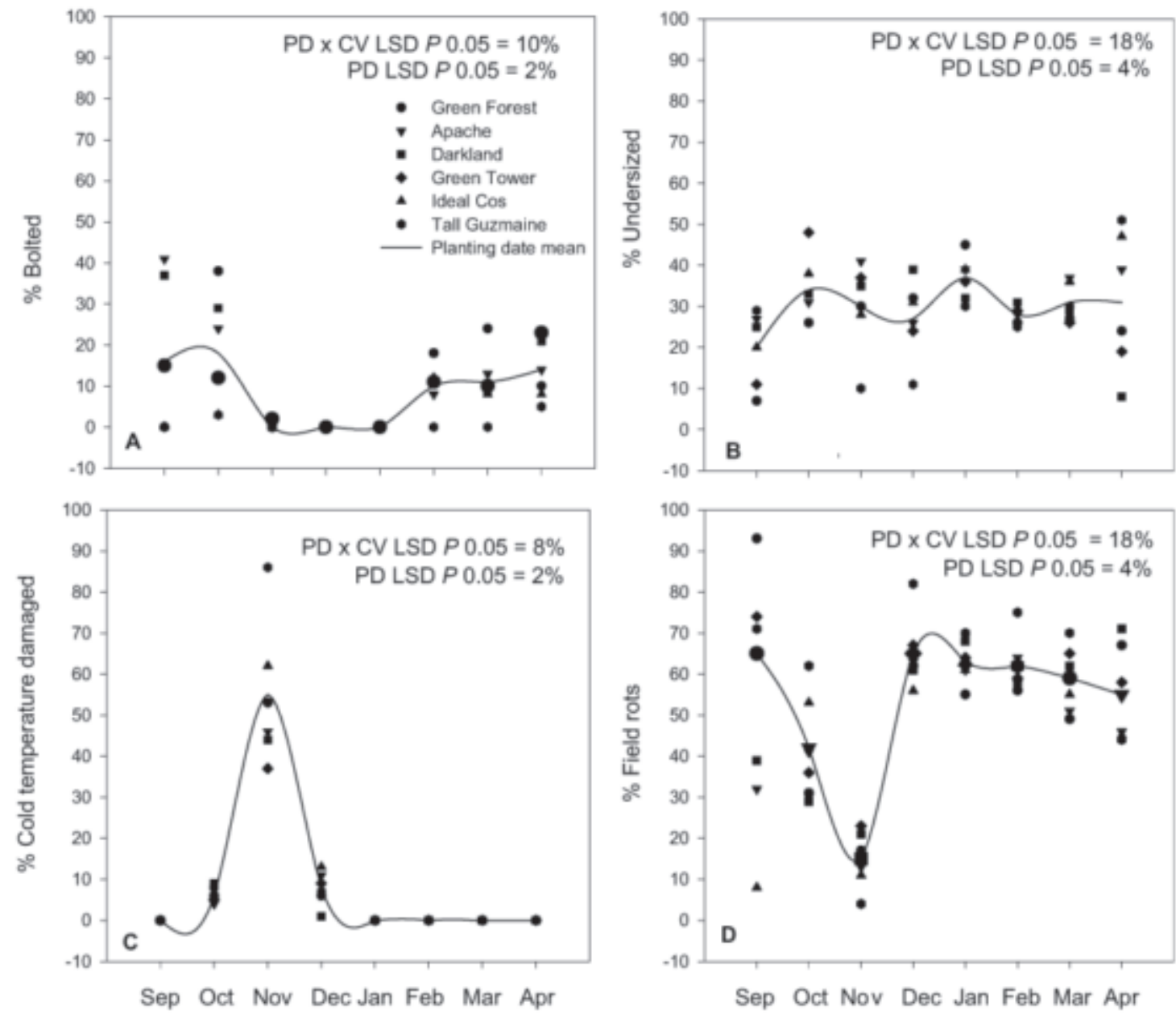

Planting date

Fig. 3. Influence of monthly planting dates from September to April 1998 to 2001 and seven romaine lettuce cultivars in Charleston, S.C., on incidence of cull head defects including (a) bolting, (b) undersized heads, (c) cold temperature damaged heads, and (d) field rots.

PD GSs, with November and February PD GSs intermediate, and the lowest incidence of undersized heads in December and September PD GSs. (Fig. 3b).

As expected, the majority of variation in cold damaged heads was due to the PD main effect with minor but significant portions of variation assigned to cultivar and the interaction of cultivar with PD (Table 2). Fourteen percent of all culls in 1998 were cold temperature damaged with only $2 \%$ in 1999 and $11 \%$ in 2000 (data not shown). Cold damaged heads were very common in November PD GS with minor problems in October and December PD GSs with no cold damage in September, January through April PD GSs (Fig. 3c).

Cull yields (numbers per plot) were greater in 1999 and similar in1998 and 2000 (data not shown). Cull production significantly varied by PDs (pooled over cultivar and year) and was greatest in April $>$ December $(-5 \%$ decrease from April) $>$ January $=$ February $(-16 \%)$ $>$ November $(-27 \%)>$ October $(-34 \%)>$ March $(-44 \%)>$ September $(-49 \%)$ PD GSs (Fig. 2d). If the two November PDs that were lost to freezing damage were included, the November PD would rank as the greatest PD for cull production.

The climate during the September through December PD GSs had a unique effect on cull production with the various cultivars responding differentially by PD. The September PD had fewer culls than any other PD (cultivar and year pooled), but the cultivars varied significantly in cull production by PD (Fig. 2d). DK, AP, and TG yielded the most culls in the September PD GS with GT and IC intermediate and GF significantly lowest of all. Field rots were the major cull defect with 93\% of GF culls classified as rots (Fig. 3d). Bolting was a problem during the September PD GS especially for AP and DK, intermediate for GT, but TG, IC, and GF resisted bolting entirely (Fig. 3a). In the October PD GS, cull yield increased $24 \%$ from the September PD GS with all the cultivars producing similar cull yields except TG which produced fewer culls. During the October PD GS, GF bolted more, AP and DK intermediate, and GT and IC bolted less and none of TG culls were classified as bolted during the October PD GS. Commercially, the November PD GS is very risky since two out of three years were lost due to freezing. In the only successful November
PD, cull production increased $8 \%$ from the October PD with TG and IC yielding more culls than DK, GT, GF, with AP yielding the least. The cultivars displayed different cold tolerance during the November PD GS, with the majority of TG culls damaged by cold temperatures, followed by IC $>$ GF $=\mathrm{AP}$, but $\mathrm{DK}$ and $\mathrm{GT}$ experienced the least cold damage (Fig. 3c). Average temperatures during the December PD GS averaged about 4.4,3.3, and $4.5^{\circ} \mathrm{C}$ (max, mean, min, respectively) cooler than the November PD GS temperatures (Table 2 ) and these sublethal temperatures increased the incidence of disease and subsequent head collapse. Cull production increased $24 \%$ in the December PD from the November PD with TG producing the most culls ( $82 \%$ were field rots), GF and IC producing the least, and AP, DK, GT intermediate.

In the January through April PD GSs, average temperatures warmed again with January PD GS temperatures averaging 2.2, 1.7, and $0.6^{\circ} \mathrm{C}$ warmer (max, mean, min, respectively) than the December PD GS (Table 2). Field rots were a major problem during the January PD GS (Fig. 3d) and cold temperatures may have injured developing heads, increasing the 
spread of disease and subsequent head collapse. Generally, cull production decreased $10 \%$ from the December to January PD GS; however, TG and DK produced the most culls during the January PD GS with fewer culls with GF $=\mathrm{AP}=\mathrm{IC}=\mathrm{GF}$ (Fig. 2d). Cull production in the February PD GS was similar to the January PD GS; however, GT and TG produced the most culls with GF, AP, and IC yielding fewer culls in contrast, with DK intermediate. In general, $10 \%$ of all culls bolted so the climate during the February PD GS was more conducive for vernalization for all cultivars, except TG which did not experience any bolting (Fig. 3a). In the March PD GS, culls decreased $33 \%$ compared with the February PD GS, with TG, AP, DK, and IC similar in cull production, but GF had the least culls. GF bolted the most ( $24 \%$ of all culls) with less bolting with AP, DK, GT, IC, and TG resisted bolting entirely. Temperatures during the April PD GS were similar to the September PD GS and averaged $3.3{ }^{\circ} \mathrm{C}$ warmer than the March PD GS. Culls increased $44 \%$ compared to the March PD GS with TG producing the most culls and $>$ $\mathrm{AP}>\mathrm{DK}=\mathrm{GT}=\mathrm{IC}>\mathrm{GF}$. Bolting decreased significantly from the March to April PD GSs for GF (54\%), increased $57 \%$ for DK and GT, but remained the same for AP, IC, and only $5 \%$ of TG culls bolted.

\section{Summary}

Although this study did not include a detailed examination of the use of heat unit summations to predict lettuce maturity, the data indicated that romaine lettuce yields improved, in general, when grown in warmer in contrast to colder GSs. In warmer climates, more heat units accumulate faster and growth, development and maturity are accelerated. Al-Harbi (2001) found a similar situation in the Middle East in that the greatest vegetative growth and yield of lettuce (Lactuca sativa) occurred in the earliest and warmest PDs and delaying planting into colder months, reduced growth and earliness. In our study, the warmest average temperatures occurred in September, October, March, and April PD GSs and marketable yields were much greater than the cooler PDs of November, December, January, and February. Planting this cool season crop in colder months is not an impossible obstacle yet lower yields should be expected and not all cultivars should be used during all PDs throughout the production seasons. Plantings romaine lettuce into the warmer months of spring, such as the April PD, increased marketable yield; however, cull production increased during the April PD GS to the greatest level of all PDs, especially bolting as a result of increasing daylength and temperatures which enhanced flowering. We feel that planting beyond April, however, would have been unsuccessful because it is assumed widespread bolting would naturally occurred.

To meet the changing market demands during the season, growers must make frequent lettuce plantings and combine PDs and cultivars with different growth rates (Kristensen et al., 1987). In our study, it is apparent that because of the genotype by environment interaction, cultivar choice needs to be alternated over PDs to use cultivars that synchronize well with the changing climate. The stability of a cultivar is also an important consideration in that consistent production may be more desirable than high yields when irregular yields contribute to problems with marketing and pricing policy (Pritts and Luby, 1990). Although formal stability analyses were not conducted on this data, it is apparent that GF has excellent stability in changing environments since it was a top performer in 6 out of 8 PDs and would be highly recommended for commercial production in those months only. To illustrate its versatility, GF was the most productive cultivar in the December PD GS, the coldest PD of all, as well as the April PD GS, the warmest PD and most prone to bolting. Less stable cultivars apparently synchronized well with only unique, very specific climatic conditions that enhanced their yield and quality characteristics prevalent during some of the PDs. Of all the cultivars, apparently TG was the least stable cultivar since it yielded the greatest number of marketable heads only in the October PD GS and then ranked inferior in the remaining 7 PDs.
The data reported here are generally consistent with earlier workers cited in the introduction that yield and quality may be unique to specific genotype/environment combinations. This study strongly offers a firm rationale that cultivar performance and screening of cultivars for commercial adaptation in a region needs to be performed locally under a wide range of contrasting environments to determine and identify the most stable, well-adapted cultivars for a particular growing season. Cultivar trials conducted on one solitary PD may be flawed without multiple PDs which consider the effect of diverse climatic influences on yield and quality.

\section{Literature Cited}

Al-Harbi, A.R. 2001. Growth and flowering of five lettuce cultivars as affected by planting date. J. Veg. Crop Prod. 7:23-36.

Kobryn, J. 2001. Effect of planting date on pak choi and butterhead lettuce growth, yield and quality characteristics. Ann. Warsaw Agr. Univ., Hort. 22:43-48.

Kristensen, S., E. Friis, K. Henriksen, and S.A. Mikkelson. 1987. Application of temperature sums in the timing of production of crisp lettuce. Acta Hort. 198:217-226.

Pritts, M. and J. Luby. 1990. Stability indices for horticultural crops. HortScience 25:740-745.

Ryder, E.J. 1999. Lettuce, endive and chicory. CAB Intl. Publ., UK.

Sanders, D., 2005. Vegetable crop guidelines for the southeastern U.S. Helena Chemical Co., Memphis, Tenn.

Sharma, D.K., D.R. Chaudhary, and D.P. Pandey. 2001. Growth and yield of lettuce cv. Alamo-1 as influence by dates of planting and plant density. Veg. Sci. 1:38-39.

U.S. Dept. of Agriculture. 1960. United States standards for grades of romaine. USDA, Wash., D.C.

U.S. Dept. of Agriculture. 2005. Commodity highlight: Romaine lettuce. Veg. Melons Outlook, VGS-307.

Vaus, P. N. de. 1976. Comparison of lettuce cultivars sown at four different times. J. Agr. 74:225.

Wurr, D.C., J.R. Fellows, and R.F. Suckling. 1988. Crop continuity and prediction of maturity in the crisp lettuce variety Saladin. J. Agr. Sci. 3:481-486. 